\title{
Expression of IRT1 gene in barley seedlings under zinc deficiency at opti- mal and low temperatures
}

\author{
Natalia KAZNINA ${ }^{1,2}$, Natalia REPKINA ${ }^{1}$, Yulia BATOVA ${ }^{1}$, Alexandr TITOV ${ }^{1}$ \\ Received December 17, 2020; accepted October 21, 2021. \\ Delo je prispelo 17. decembra 2020, sprejeto 21. oktobra 2021
}

Expression of IRT1 gene in barley seedlings under zinc deficiency at optimal and low temperatures

Abstract: The deficiency or excess of zinc ( $\mathrm{Zn}$ ) cause negative effect on plant metabolism and development. Therefore, plants have established a tightly controlled system, including protein transporters to balance the uptake and utilization of metal ions. In this study, the relative expression of HvIRT1 gene, encoding the transmembrane protein IRT1 was analyzed in shoots and roots of barley (Hordeum vulgare 'Nur') under zinc deficiency at optimal $\left(22^{\circ} \mathrm{C}\right)$ or low $\left(4^{\circ} \mathrm{C}\right)$ temperatures. The Zn deficiency $(0 \mu \mathrm{mol})$ caused an increase in HvIRT1 gene expression under both optimal temperature condition and cold. Although, the difference in mRNA content of HvIRT1 gene in roots of barley under optimal and low temperature was not observe. However, the HvIRT1 expression in leaves was higher at optimal temperature compare with cold condition. Moreover, long-term (7 days) of low temperature influence along with zinc deficiency leads to a significant decrease in the amount of HvIRT1transcripts in leaves, that corresponds to a decrease of photosynthesis rate and biomass accumulation. Overall, these findings suggest that HvIRT1 gene play an important role in plant's response to zinc deficiency under optimal temperatures condition as well as at cold.

Key words: IRT1; Hordeum vulgare; zinc deficiency; low temperatures
Izražanje IRT1 gena v sejankah ječmena ob pomanjkanju cinka pri optimalnih in nizkih temperaturah

Izvleček: Pomanjkanje ali prebitek cinka $(\mathrm{Zn})$ povzročata negativne učinke na presnovo in razvoj rasttlin. Zaradi tega so rastline razvile dobro nadzorovan sistem, vključno s proteinskimi transporterji za uravnavanje privzema in porabe kovinskih ionov. V raziskavi je bilo analizirano izražanje $H v I R T 1$ gena, ki kodira transmembranski protein IRT1 v poganjkih in koreninah ječmena (Hordeum vulgare 'Nur') ob pomankanju zinka pri optimalni $\left(22^{\circ} \mathrm{C}\right)$ in nizki $\left(4^{\circ} \mathrm{C}\right)$ temperaturi. Pomanjkanje cin$\mathrm{ka}(0 \mu \mathrm{mol})$ je povzročilo povečano izražanje HvIRT1 gena pri optimalni kot pri nizki temperaturi. Razlika v vsebnosti mRNK HvIRT1 gena v koreninah ječmena v optimalnih razmerah in pri nizki temperaturi ni bila opažena, a kljub temu je bilo izražanje gena $H v I R T 1$ v listih večje pri optimalni temperaturi v primerjavi s hladnimi rastnimi razmerami. Daljša izpostavitev (7 dni) nizki temperature je ob pomanjkanju cinka povzročila značilno zmanšanje transkriptov HvIRT1 v listih, kar ustreza upadu fotosinteze in akumulacije biomase. Ta odkritja nakazujejo, da igra HvIRT1 gen pomembno vlogo pri odzivu rastlin na pomanjkanje cinka tako $\mathrm{v}$ optimalnih razmerah kot pri nizkih temperaturah.

Ključne besede: IRT1; Hordeum vulgare; pomanjkanje cinka; nizke temperature

1 Institute of Biology, Karelian Research Centre, Russian Academy of Sciences, Petrozavodsk, Russia

2 Corresponding author, e-mail: kaznina@krc.karelia.ru 


\section{INTRODUCTION}

Zn deficiency has been recognized as an important factor affecting crop production. Cell transmembrane proteins from ZIP family (zinc-iron-regulated transporter) play an important role in providing plants of the necessary amount of zinc (Pedas et al., 2008; Lee and An, 2009; Yamunarani et al., 2013). The IRT1 (ironregulated transporter1) proteins, belonging to the ZIP family, were firstly discovered in cereals. ZIP proteins are able to transport various divalent cations, such as $\mathrm{Fe}^{2+}$, $\mathrm{Zn}^{2+}, \mathrm{Cu}^{2+}, \mathrm{Mn}^{2+}$ from the rhizosphere through the plasma membrane into the cytoplasm of root cells, as well as from xylem vessels in leaf mesophyll cells (Palmer and Guerinot, 2009). It has been reported that zinc deficiency leads to increase in the activity of IRT1 protein and IRT1 gene expression in parallel with high accumulation of $\mathrm{Zn}$ in roots and shoots of rice, maize and Arabidopsis (Ishimaru, 2006; Pedas et al., 2008; Yamunarani et al., 2013; Kabir et al., 2017 etc.). Therefore, IRT1 protein play essential role in $\mathrm{Zn}$ uptake, translocation and storage of $\mathrm{Zn}$ in plant cells especially under $\mathrm{Zn}$ deficiency. Although, most of the evidence from these studies was performed on plants under optimal temperature conditions, however, in nature plants are often exposed to low temperatures during the growing season, that caused in decrease in supply of nutrients to root cells, that result in their deficiency in plants (Hacisalihoglu et al., 2001). Perhaps this effect may be associated with a decrease in the activity of transport proteins (Guerinot, 2000; Hacisalihoglu et al., 2001). Despite this data, the effect of cold on IRT1 gene expression and IRT1 protein activity is still unclear. Some reports demonstrated that the IRT1 protein activity regulated at the both translation and transcription level (Shin et al., 2013; Brumbarova et al., 2015). According these findings, we studied the expression of the IRT1 gene in the roots and leaves of barley under zinc deficiency at optimal and low temperatures.

\section{MATERIALS AND METHODS}

\subsection{PLANT MATERIAL AND GROWTH CONDI- TIONS}

Seeds of barley (Hordeum vulgare 'Nur')were purchased from the Tula Research Institute of Agriculture, Tula, Russia. Seedlings were cultivated in a growth chamber with $14 \mathrm{~h}$ photoperiod, a photo-synthetic photon flux density of $180 \mu \mathrm{mol} \mathrm{m}^{-2} \mathrm{~s}^{-1}$, a temperature of $22{ }^{\circ} \mathrm{C}$ and a relative humidity of $60-70 \%$ on Hoagland-Arnon nutrient solution (pH 6.2 to 6.4) with optimal (variant $\mathrm{Zn} 2$ $\mu \mathrm{mol}+22^{\circ} \mathrm{C}$ ) zinc content or its deficiency (variant $\mathrm{Zn}$
$0 \mu \mathrm{mol}+22{ }^{\circ} \mathrm{C}$ ). Seven-day-old seedlings (initial level) were separated. One part of the plants of both variants was exposed to low temperature $\left(4^{\circ} \mathrm{C}\right)$ (variants $\mathrm{Zn} 2$ $\mu \mathrm{mol}+4{ }^{\circ} \mathrm{C}$ and $\mathrm{Zn} 0 \mu \mathrm{mol}+4{ }^{\circ} \mathrm{C}$ ), and the other part was left under the optimal temperature during 7 days. All parameters were measured at day 0 (initial level) and 1,3 , 7 days after treatments.

\subsection{BIOMASS AND NET PHOTOSYNTHETIC RATE DETERMINATION}

For biomass determination plants were collected, their shoots and roots separated and dried in an oven at $85{ }^{\circ} \mathrm{C}$ for $24 \mathrm{~h}$. The net photosynthetic rate $\left(\mathrm{P}_{\mathrm{N}}\right)$ was measured during a day using portable photosynthesis system HCM-1000 (Walz, Effeltrich, Germany).

\subsection{GENE EXPRESSION}

The expression pattern of HvIRT1 gene in leaves and roots was monitored by real-time PCR. Frozen roots and leaf tissues were homogenized with liquid nitrogen. Total RNA was extracted using a TRizol reagent (Evrogen, Moscow, Russia) as instructed by them anufacturer. The total RNA was treated with RNase free DNase (Syntol, Moscow, Russia) to remove genomic DNA. The purity of RNA samples and their concentrations were determined spectrophotometrically (SmartSpecPlus, Bio-Rad, Hercules, USA): samples withA260/A280 ratios within 1.8 - 2.0 were used for further analysis. The total RNA $(1 \mu \mathrm{g})$ was reverse-transcribed using a MMLV RT kit (Evrogen) following the supplier's recommendations. Real-time quantitative PCR was performed using the $i C y c l e r i Q$ detection system (Bio-Rad). Analyzes were performed using a SYBR Green PCR kit (Evrogen). The PCR conditions consisted of denaturation at $95^{\circ} \mathrm{C}$ for 5 min followed by 45 cycles of denaturation at $95^{\circ} \mathrm{C}$ for $15 \mathrm{~s}$, annealing at $56{ }^{\circ} \mathrm{C}$ for 30 s, and extension at $72{ }^{\circ} \mathrm{C}$ for 45 s. A dissociation curve was generated at the end of each PCR cycle to verify that a single product was amplified using $i$ Cycler $i Q$. To minimize sample variations, mRNA expression of a target gene was normalized relative to the expression of a housekeeping gene actin. The mRNA content of target gene (HvIRT1) were quantified in comparison to the actin by the $\Delta \Delta \mathrm{Ct}$ method (Livak and Schmittgen, 2001). Primers were designed (using the Primer Design program): HvActin (U21907) ATGTTTTTTTCCAGACG (direct) and ATCCAAGCCAACCCAAGT (reverse), HvIRT1 (EU54802) GTGCTTCCACCAGATGTTTGAG (direct) andGGATGCCGACGACGATGA (reverse). 


\subsection{STATISTICAL ANALYSIS}

All data are presented as means \pm standard errors (SEs) from at least three independent replicates. Significant differences between variants and relative to the initial level were calculated by two-way analysis of variance (ANOVA) using Microsoft Excel 2010. Student's t-test was applied to compare statistical significance at level of $p<0.05$.

\section{RESULTS AND DISCUSSION}

Table 1 shows the effect of $\mathrm{Zn}$ deficiency under optimal and low temperatures on plant dry mass (DM) accumulation and net photosynthetic rate $\left(\mathrm{P}_{\mathrm{N}}\right)$. Under optimal temperature conditions Zn deficiency did not significant affect the $\mathrm{DM}$ and $\mathrm{P}_{\mathrm{N}}$ parameters compare with plants grown with optimal $\mathrm{Zn}$ concentration. However, after 7 days Zn deficiency $\left(\mathrm{Zn} 0 \mu \mathrm{mol}+22^{\circ} \mathrm{C}\right)$ caused slightly reduction root DM compare with variant $\mathrm{Zn} 2 \mu \mathrm{mol}+22^{\circ} \mathrm{C}$.

Despite the $\mathrm{Zn}$ concentration the low temperature leads to reduce $\mathrm{DM}$ accumulation and $\mathrm{P}_{\mathrm{N}}$ parameter. $\mathrm{Al}$ though, after 7 days $\mathrm{Zn}$ deficiency in combination with low temperature ( $\mathrm{Zn} 0 \mu \mathrm{mol}+4{ }^{\circ} \mathrm{C}$ ) leads to significant decrease in root $\mathrm{DM}$ and photosynthesis activity compare with variant $\mathrm{Zn} 2 \mu \mathrm{mol}+4{ }^{\circ} \mathrm{C}$.

Under optimal growth conditions (variant $\mathrm{Zn} 2$ $\mu \mathrm{mol}+22^{\circ} \mathrm{C}$ ) the transcript level of HvIRT1 gene gradually increase in roots and leaves of barley during 7 days (Fig.).While, at the initial level, the HvIRT1 gene expression was 3-fold higher in roots seedlings grown with $\mathrm{Zn}$ deficiency $\left(\mathrm{Zn} 0 \mu \mathrm{mol}+22{ }^{\circ} \mathrm{C}\right)$. Further HvIRT1 gene mRNA content in variant $\mathrm{Zn} 0 \mu \mathrm{mol}+22^{\circ} \mathrm{C}$ slightly increased in compare with variant $\mathrm{Zn} 2 \mu \mathrm{mol}+22^{\circ} \mathrm{C}$. At the initial level there was no significant difference in mRNA content of HvIRT1 gene in leaves between $\mathrm{Zn} 2$ $\mu \mathrm{mol}+22{ }^{\circ} \mathrm{C}$ and variant $\mathrm{Zn} 0 \mu \mathrm{mol}+22{ }^{\circ} \mathrm{C}$ variants (Fig.). However, leaves of barley exposed to $\mathrm{Zn}$ deficiency (Zn $0 \mu \mathrm{mol}+22^{\circ} \mathrm{C}$ ) showed higher the HvIRT1mRNA content within 1 day and slightly decrease on seventh day in compare with $\mathrm{Zn} 2 \mu \mathrm{mol}+22^{\circ} \mathrm{C}$ variant.

Low temperature caused an increase in HvIRT1 gene expression in roots along with time of exposure in both variants ( $\mathrm{Zn} 2 \mu \mathrm{mol}+4{ }^{\circ} \mathrm{C}$ and $\mathrm{Zn} 0 \mu \mathrm{mol}+4{ }^{\circ} \mathrm{C}$ ) (Fig.). However, on $7^{\text {th }}$ day of experiment the amount of HvIRT1 gene transcripts in roots of barley variant $\mathrm{Zn} 0$ $\mu \mathrm{mol}+4{ }^{\circ} \mathrm{C}$ were greater than in variant $\mathrm{Zn} 2 \mu \mathrm{mol}+4$ ${ }^{\circ} \mathrm{C}$. Low temperature resulted in $H v I R T 1$ gene transcript accumulation in leaves of barley variant $\mathrm{Zn} 2 \mu \mathrm{mol}+4$ ${ }^{\circ} \mathrm{C}$. After 1 day of cold impact the HvIRT1 gene expression was 4 -fold higher in variant $\mathrm{Zn} 2 \mu \mathrm{mol}+4^{\circ} \mathrm{C}$ com- pare with initial level and 10-fold higher on seven day of experiment. In variant $\mathrm{Zn} 0 \mu \mathrm{mol}+4{ }^{\circ} \mathrm{C}$ the $H v I R T 1$ gene mRNA content increased after 3 days of exposure to low temperature and significant decreased on seven day of experiment.

In general, our results demonstrated a high tolerance of barley 'Nur' to $\mathrm{Zn}$ deficiency. It was shown that under conditions of zinc deficiency, the accumulation of biomass and photosynthetic activity remained stable until the end of the experiment. Similar data were described previously (Hajiboland and Beiramzadeh. 2008; Kabir et al., 2017). The capability of plants to grow under $\mathrm{Zn}$ deficiency mostly depend on metal transporters activity, including protein IRT1 (Suzuki et al., 2012; Yamunarani et al., 2013; Kabir et al., 2017). Zn deficiency under optimal temperature leads to increase in HvIRT1 transcript amount in roots and leaves of barley that resulted in activation of transport metal ions in cells and kept growth and photosynthetic activity. This also support the fact that after 7 days the gene expression of HvIRT1 decreased along with photosynthetic activity. The negative effect of $\mathrm{Zn}$ deficiency on photosynthesis process was described previously in Oryza sativa L. (Hajiboland and Beiramzadeh, 2008), Zea mays L. (Liu et al., 2016), Sorgum bicolor (L.) Moench (Li et al., 2013), however the transport protein activity was not studied.

There are fragmentary data about influence of low temperature on metal transporters activity. The negative effect of $0^{\circ} \mathrm{C}$ temperature on gene expression, encoding protein transporters ZIP1 and ZIP3 was described previously (Grotz et al., 1998). We have also shown the increase in HvIRT1 gene expression in barley under chilling (Kaznina et al., 2019). It is supposed that due to negative influence of chilling on nutrient transport into cells the increase in HvIRT1 gene expression in roots that we reported can be a result of requirement of mesophyll cells of leaves in nutrients that are necessary for photosynthesis process. There are no data about activity of transporter proteins under chilling and $\mathrm{Zn}$ deficiency condition. Thus considering the results described above for barley under low temperature and $\mathrm{Zn}$ deficiency during 7 days in leaves the HvIRT1 mRNA content significantly decreased. It seems to be a result of decrease in requirement in nutrients caused by slowdown of photosynthetic activity and growth of seedlings under stress conditions. Additionally, it can be a result of interruption in signal transduction from leaves to roots that was demonstrated previously in plants under chilling and optimal nutrient level (Giehl et al., 2009; Romera et al., 2011). 
Table 1: The effect of zinc deficiency on the root and shoot dry biomass and photosynthesis rate of barley plants 'Nur' at optimum $\left(22^{\circ} \mathrm{C}\right)$ and low $\left(4^{\circ} \mathrm{C}\right)$ temperatures

\begin{tabular}{|c|c|c|c|c|}
\hline \multirow[b]{2}{*}{ Variant } & \multicolumn{4}{|c|}{ Time, days } \\
\hline & 0 (initial point) & 1 & 3 & 7 \\
\hline & \multicolumn{4}{|c|}{ Dry root biomass, mg } \\
\hline $\mathrm{Zn} 2+22^{\circ} \mathrm{C}$ & $5.51 \pm 0.55 \mathrm{aA}$ & $6.72 \pm 0.48 \mathrm{aA}$ & $7.29 \pm 0.42 \mathrm{bA}$ & $8.21 \pm 0.60 \mathrm{bA}$ \\
\hline $\mathrm{Zn} 0+22^{\circ} \mathrm{C}$ & $5.10 \pm 0.45 \mathrm{aA}$ & $6.51 \pm 0.41 \mathrm{aA}$ & $6.92 \pm 0.38 \mathrm{bA}$ & $7.96 \pm 0.46 \mathrm{bA}$ \\
\hline $\mathrm{Zn} 2+4^{\circ} \mathrm{C}$ & $5.51 \pm 0.55 \mathrm{aA}$ & $6.20 \pm 0.47 \mathrm{aA}$ & $6.26 \pm 0.48 \mathrm{aB}$ & $7.36 \pm 0.54 \mathrm{bAB}$ \\
\hline \multirow[t]{2}{*}{$\mathrm{Zn} 0+4^{\circ} \mathrm{C}$} & $5.10 \pm 0.45 \mathrm{aA}$ & $6.13 \pm 0.29 \mathrm{aA}$ & $6.23 \pm 0.35 \mathrm{aB}$ & $6.36 \pm 0.46 \mathrm{aB}$ \\
\hline & \multicolumn{4}{|c|}{ Dry shoot biomass, mg } \\
\hline $\operatorname{Zn} 2+22^{\circ} \mathrm{C}$ & $20.13 \pm 1.88 \mathrm{aA}$ & $20.89 \pm 1.21 \mathrm{aA}$ & $27.21 \pm 1.48 \mathrm{bA}$ & $31.32 \pm 2.41 \mathrm{bA}$ \\
\hline $\mathrm{Zn} 0+22^{\circ} \mathrm{C}$ & $18.99 \pm 1.89 \mathrm{aA}$ & $19.51 \pm 1.09 \mathrm{aA}$ & $24.06 \pm 1.62 \mathrm{bA}$ & $32.13 \pm 1.32 \mathrm{bA}$ \\
\hline $\mathrm{Zn} 2+4^{\circ} \mathrm{C}$ & $20.13 \pm 1.88 \mathrm{aA}$ & $20.00 \pm 1.51 \mathrm{aA}$ & $20.87 \pm 1.50 \mathrm{aB}$ & $24.77 \pm 1.39 \mathrm{bB}$ \\
\hline \multirow[t]{2}{*}{$\mathrm{Zn} 0+4^{\circ} \mathrm{C}$} & $18.99 \pm 1.89 \mathrm{aA}$ & $19.63 \pm 1.16 \mathrm{aB}$ & $18.42 \pm 0.95 \mathrm{aC}$ & $19.28 \pm 1.21 \mathrm{aC}$ \\
\hline & \multicolumn{4}{|c|}{ Net photosynthetic rate, $\mu \mathrm{mol} \mathrm{CO} \mathrm{C}^{2} \cdot \mathrm{s}^{-1}$} \\
\hline $\mathrm{Zn} 2+22^{\circ} \mathrm{C}$ & $6.82 \pm 0.16 \mathrm{aA}$ & $7.77 \pm 0.17 \mathrm{bA}$ & $6.54 \pm 0.50 \mathrm{aA}$ & $6.53 \pm 0.10 \mathrm{aA}$ \\
\hline $\mathrm{Zn} 0+22^{\circ} \mathrm{C}$ & $6.95 \pm 0.14 \mathrm{aA}$ & $7.69 \pm 0.14 \mathrm{bA}$ & $6.46 \pm 0.49 \mathrm{aA}$ & $6.27 \pm 0.12 \mathrm{aA}$ \\
\hline $\mathrm{Zn} 2+4^{\circ} \mathrm{C}$ & $6.82 \pm 0.16 \mathrm{aA}$ & $4.65 \pm 0.20 \mathrm{bB}$ & $4.86 \pm 0.12 \mathrm{bB}$ & $4.16 \pm 0.09 \mathrm{cB}$ \\
\hline $\mathrm{Zn} 0+4^{\circ} \mathrm{C}$ & $6.95 \pm 0.14 \mathrm{aA}$ & $4.83 \pm 0.12 \mathrm{bB}$ & $4.35 \pm 0.15 \mathrm{bB}$ & $3.82 \pm 0.17 \mathrm{cC}$ \\
\hline
\end{tabular}

Different lowercase letters indicate significant differences in columns (between variants), uppercase letters - in rows (relative to the initial level) $(p<$ 0.05).Values perform mean $\pm \operatorname{SE}(\mathrm{n}=10)$
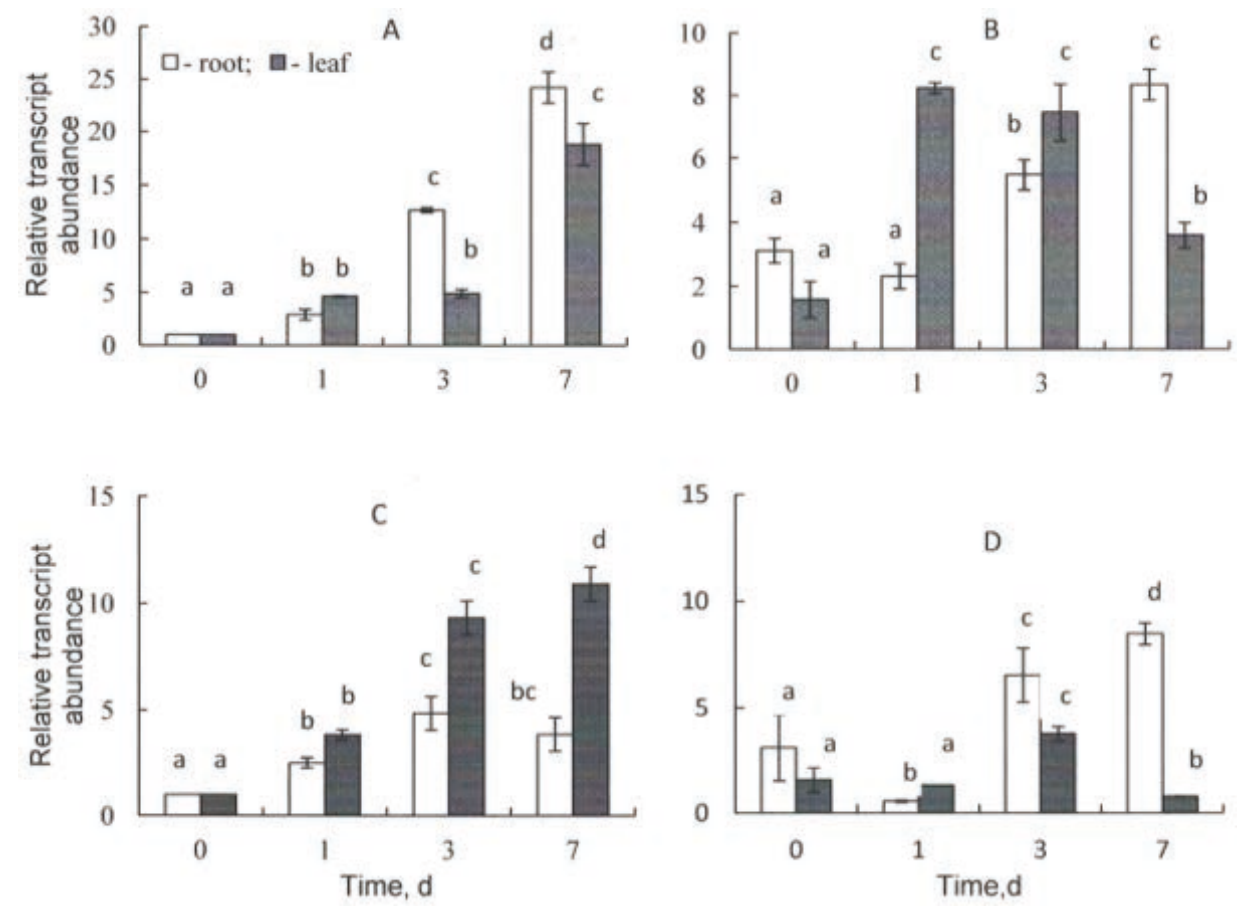

Figure 1: The effect of zinc optimum (a, c) and zinc deficiency (b, d) on HvIRT1 gene transcription in the roots and leaves of barley plants 'Nur' at $22^{\circ} \mathrm{C}(\mathrm{a}, \mathrm{b})$ and $4{ }^{\circ} \mathrm{C}(\mathrm{c}, \mathrm{d})$. Different lowercase letters indicate significant differences relative to the initial level $(p<0.05)$ 


\section{CONCLUSIONS}

According to our results it was shown that Zn deficiency caused in increase in HvIRT1 gene expression in leaves of barley not only under optimal temperature as was shown in another reports but also under cold. For the first time we demonstrated that long-term exposure (7 days) to low temperature leads to significant decrease in HvIRT1 mRNA amount in leaves in parallel to slow down in photosynthetic activity and growth. Taken together, the results presented here illustrate the participation of the HvIRT1 gene in adaptation to $\mathrm{Zn}$ deficiency under optimal and low temperatures conditions.

\section{ACKNOWLEDGEMENTS}

This research was carried out using the equipment of the Core Facility of the Karelian Research Centre of the Russian Academy of Sciences and under state order (No. 0218-2019-0074).

\section{REFERENCES}

Brumbarova, T, Bauer, P, Ivanov, R (2015). Molecular mechanisms governing Arabidopsis iron uptake. Trends in Plant Science, 20(2), 124-133. https://doi.org/10.1016/j. tplants.2014.11.004

Giehl, R. F. H., Meda, A.R., von Wirén, N. (2009). Moving up, down, and everywhere: signaling of micronutrients in plants. Current Opinion in Plant Biology, 12, 320-327. https://doi.org/10.1016/j.pbi.2009.04.006

Grotz,N., Fox, T., Connolly, E., Park, W., Guerinot, M.L., Eide, D. (1998). Identification of a family of zinc transporter genes from Arabidopsis that respond to zinc deficiency. Proceedings of the National. Academy of Sciences USA, 95, 7220-7224. https://doi.org/10.1073/pnas.95.12.7220

Guerinot,M.L.(2000). The ZIP family of metal transporters. Biochimica et Biophysica Acta, 1465, 190-198. https://doi. org/10.1016/S0005-2736 (00)00138-3

Hacisalihoglu,G., Hart, J.J., Kochian, L.V. (2001). High- and low- affinity zinc transport systems and their possible role in zinc efficiency in bread wheat. Plant Physiology, 125, 456-463. https://doi.org/10.1104/pp.125.1.456

Hajiboland, R., Beiramzadeh, N. (2008). Growth, gas exchange and function of antioxidant defense system in two contrasting rice genotypes under $\mathrm{Zn}$ and Fe deficiency and hypoxia. Acta Bioogica. Szegediensis, 52(2), 283-294. http://www. sci.u-szeged.hu/ABS

Ishimaru, Y., Suzuki, M., Tsukamoto, T., et al. (2006). Rice plants take up iron as an $\mathrm{Fe}^{3+}$-phytosiderophore and as $\mathrm{Fe}^{2+}$. The Plant Journal, 45, 335-346. https://doi.org/10.1111/ j.1365-313X.2005.02624.x

Kabir, A. H., Hossain, M.M., Khatun, M.A., Sarkar, M.R., Haider, S.A. (2017). Biochemical and molecular mechanisms associated with $\mathrm{Zn}$ deficiency tolerance and signaling in rice (Oryza sativa L.). Journal of Plant Interactions, 12(1), 447-456. https://doi.org/10.1080/17429145.2017.1392626

Kaznina, N.M., Titov, A.F., Repkina, N.S., Batova, Yu.V. (2019). Effect of zinc excess and low temperature on the IRT1 gene expression in the roots and leaves of barley. Doklady Biochemistry and Biophysics, 48, 264-268. https://doi. org/10.1134/S1607672919040057

Lee, S., A., G. (2009). Over-expression of OsIRT1 leads to increased iron and zinc accumulations in rice. Plant, Cell and Environment, 32, 408-416. https://doi.org/10.1111/j.13653040.2009.01935.X

Li, Y., Zhang, Y., Shi, D., Kiu, X., Qin, J, Ge, Q. .. Xu, J. (2013). Spatial-temporal analysis of zinc homeostasis reveals the response mechanisms to acute zinc deficiency in Sorghum bicolor. New Phytologist, 200, 1102-1115. https://doi. org/10.1111/nph.12434

Liu, H., Gan, W., Renge, Z., Zhao, P. (2016). Effects of zinc fertilizer rate and application method on photosynthetic characteristics and grain yield of summer maize. Journal of Soil Science and Plant Nutrition, 16(2), 550-662. https://doi. org/10.4067/S0718-95162016005000045

Livak, K.J., Schmittgen, T.D. (2001). Analysis of relative gene expression data using real-time quantitative PCR and the $2^{-\Delta \Delta c t}$ method. Methods, 25, 402-408. https://doi. org/10.1006/meth.2001.1262

Palmer, G.M., Guerinot, M.L. (2009). Facing the challenges of $\mathrm{Cu}, \mathrm{Fe}$ and $\mathrm{Zn}$ homeostasis in plants. Nature Chemical Biology, 5, 333-340. https://doi.org/10.1038/nchembio.166

Pedas, P., Ytting, C. K., Fuglsang, A. T., Jahn, T. P., Schioerring, J. K., Hasted, S. (2008). Manganese efficiency in barley: identification and characterization of the metal ion transporter HvIRT1 ${ }^{1[\mathrm{OA}]}$. Plant Physiology, 148, 455-466. https:// doi.org/10.1104/pp.108.118851

Romera, F. J., García, M. J., Alcántara, E., Pérez-Vicente, R. (2011). Latest findings about the interplay or auxin, ethylene and nitric oxide in the regulation of Fe deficiency responses by strategy I plants. Plant Signaling and Behavior, 6, 167-170. https://doi.org/10.4161/psb.6.1.14111

Shin, L.-J., Lo, J.-C., Chen, G. H., Callis, J., Fu, H., Yeh, K-C. (2013). IRT1 degradation factor 1, a ring E3 ubiquitin ligase, regulates the degradation of iron-regulated transporter1 in Arabidopsis. The Plant Cell, 25, 3039-3051. https://doi. org/10.1105/tpc.113.115212

Suzuki, M., Bashir, K., Inoue, H., Takahashi, M., Nakanishi, H., Nishizawa, N.K. (2012). Accumulation of starch in Zndeficient rice. Rice, 59, 1-8. https://doi.org/10.1186/19398433-5-9

Yamunarani, R., Ramegowda, V., Pavithra, J., Geetha, G., Rajashekar-Reddy, H., Udayakumar, M., Shankar, A. G. (2013). Expression of a rice Zn transporter, OsZIP1, increases $\mathrm{Zn}$ concentration in tobacco and finger millet transgenic plants. Plant Biotechnology Reports, 7, 309-319. https://doi.org/10.1007/s11816-012-0264-X 